\title{
Deagglomeration of High Purity Fine Alumina Powder Via pH Contro|*
}

\author{
Andanastuti Muchtar, Norazmira Wati and Nor Azri Jaafar \\ Department of Mechanical and Materials Engineering, \\ Universiti Kebangsaan Malaysia, 43600 UKM Bangi, Malaysia \\ Fax: 603-89259659 and Email: muchtar@vlsi.eng.ukm.my
}

\begin{abstract}
This paper presents results from a study on the effect of the $\mathrm{pH}$ of suspensions on the deagglomeration of a high-purity (99.99\%), fine-grained alumina powder. The $\mathrm{pH}$ of the suspension was varied between $\mathrm{pH} 2$ and 3 . It is the aim of the study to determine the best $\mathrm{pH}$ for a successful dispersion of the alumina powders in the suspension. A series of rheological studies and analytical work under Scanning Electron Microscopy were conducted. It was found that the best $\mathrm{pH}$ was $\mathrm{pH} 2$. Data obtained from rheological studies using a viscometer showed that the alumina suspension prepared at $\mathrm{pH} 2$ was least viscous, which may be taken as a negative indicator of the presence of agglomerates. This hypothesis is validated by visual inspection using SEM. For the $\mathrm{pH} 2$ samples, a successful removal of the agglomerates in the green compact has encouraged the sinterability of the samples and thus, resulted in an earlier sintering process at a low-firing temperature. In addition, the sintering characteristics and microstructures of the samples prepared with a $\mathrm{pH} 2$ suspension are also presented.
\end{abstract}

Keywords: colloidal processing, fine alumina powders, $\mathrm{pH}$ control, rheology, sintering characteristics, microstructure

\section{INTRODUCTION}

Currently dominating the advanced materials era, advanced ceramics have played critical roles in numerous engineering applications that require materials with unique and reliable capabilities. Understandably, more and more research is devoted to further develop these technical ceramics; among which, alumina, is a continuous subject of interest. Due to its inherent brittleness, numerous studies are emphasized on the research and improvement of the fracture toughness properties of alumina (Misirli et al., 1994; Muchtar and Lim, 1998). As the characteristic properties are derived from the microstructure, a significant amount of the investigations involved were directed in improving the fabrication process and the starting materials needed such that resulting alumina products acquire better mechanical performance attributes.

One major breakthrough in ceramics research recently is the successful fabrication of finegrained, high-purity alumina via colloidal processing. The technique has been used to produce agglomerate-free powder compacts, which generally exhibit superior sintering characteristics (Yeh and Sacks, 1988; Inada et al., 1990; Lim et al., 1997; Tari et al., 1998; Muchtar, 1999). As a result, the sintered products have a fine-grained structure, of the order of a

* This article has been presented orally at the Regional Symposium of Chemical Engineers (RSCE2001) in Bandung, Indonesia (29 31 October 2001). 


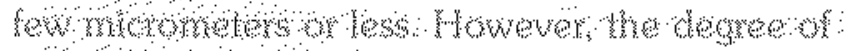

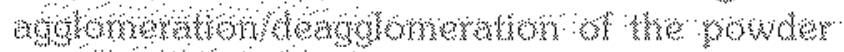

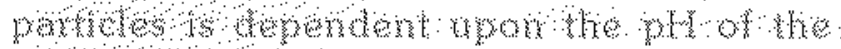

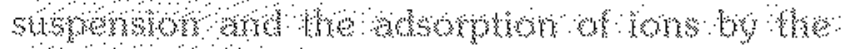

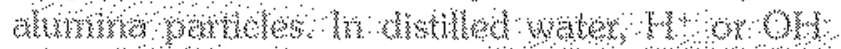

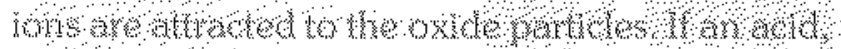

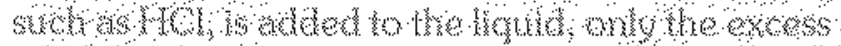

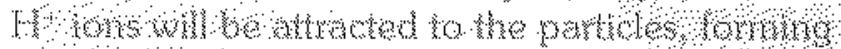

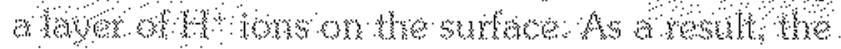

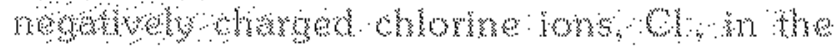

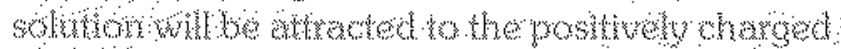

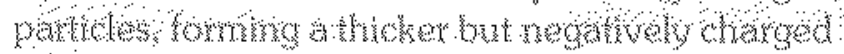

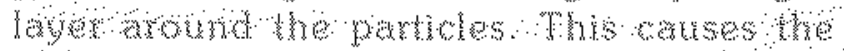

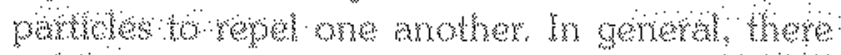

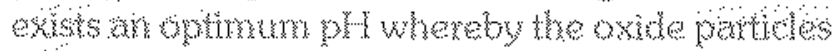
repol wech ober and thus do not fom arglowerate (Nunes ot al., 1992), The present

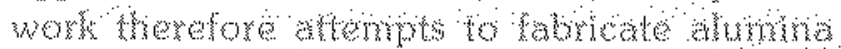

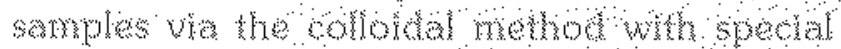

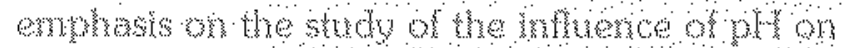

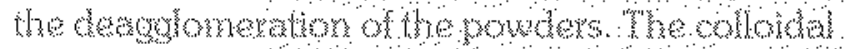

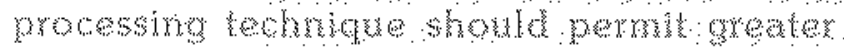

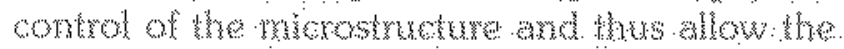

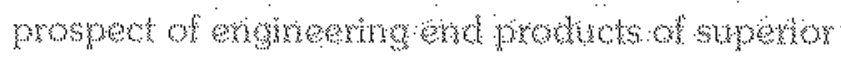
gulyy.

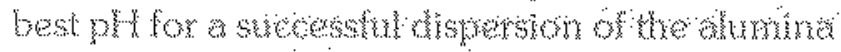

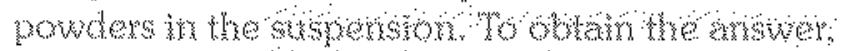

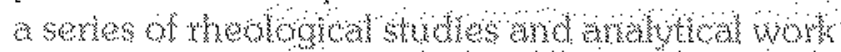

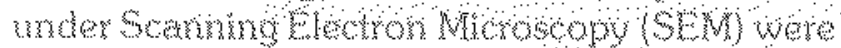

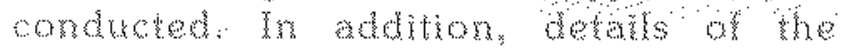

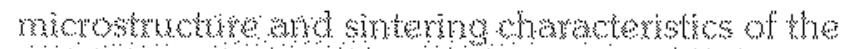

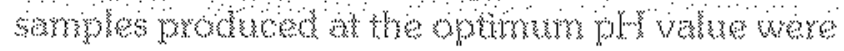
also pressured.

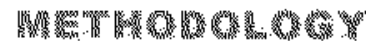

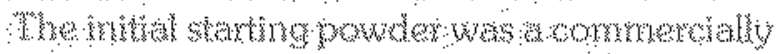

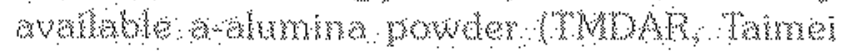

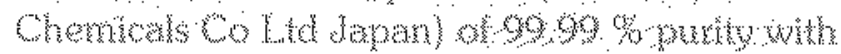

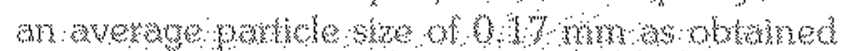

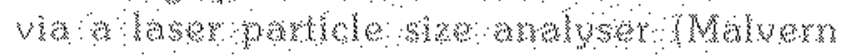

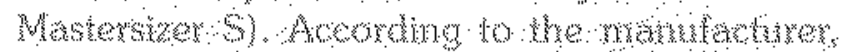

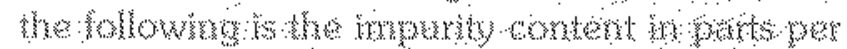

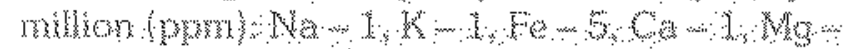

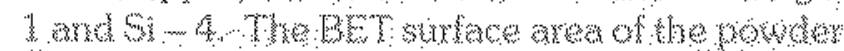

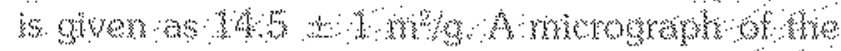

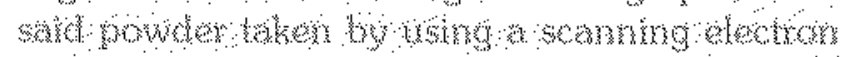

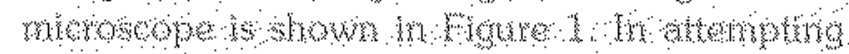

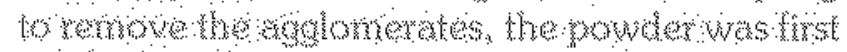

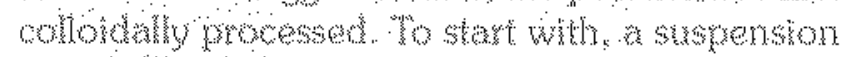

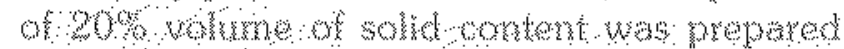

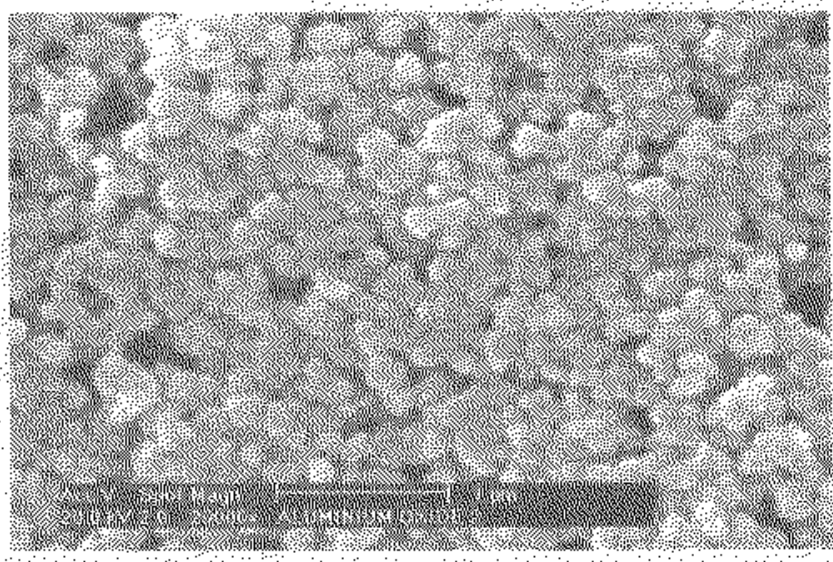

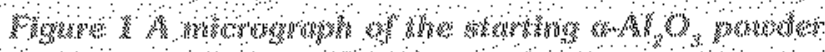
* w

using distled water this is followed by the

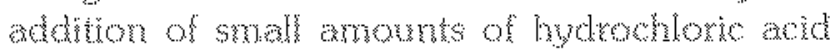
(HCH to bed bow we sof agglomerates

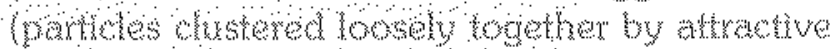

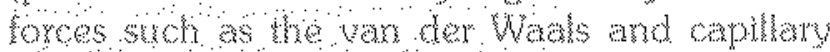

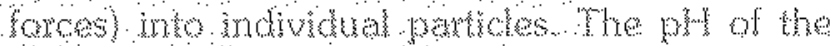

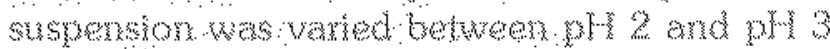

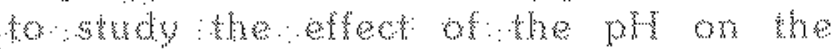

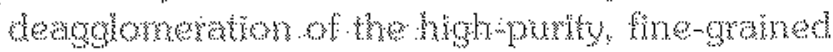

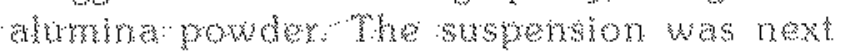

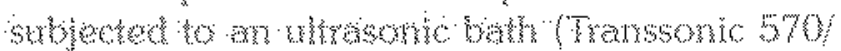

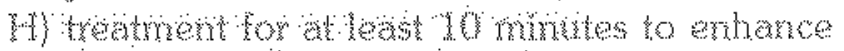

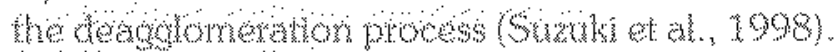
Filow whe deromertor promes of the sof

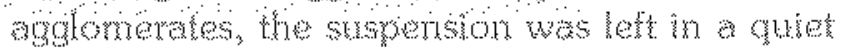
comar of the laboratory a sechnentaton perow

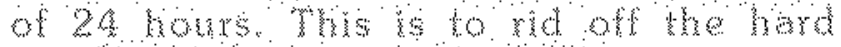

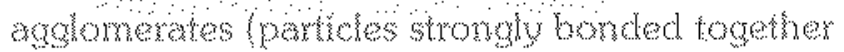
by proceses such as calchations oung powder

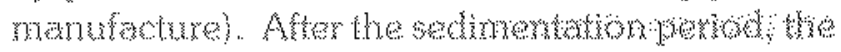
hard aghomerates fomed athin layer of sedrment

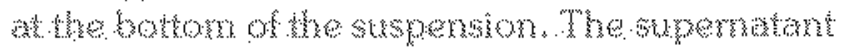

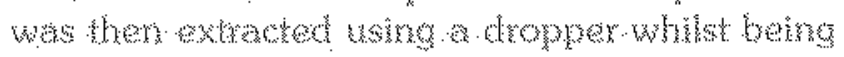

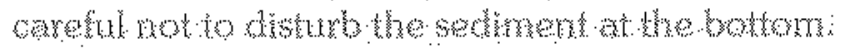

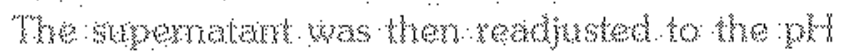

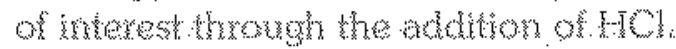

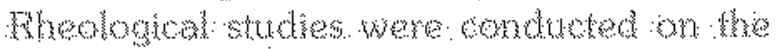

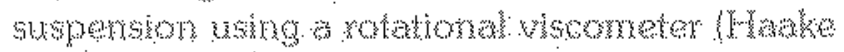

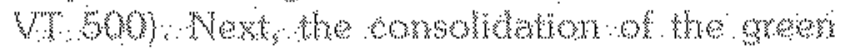

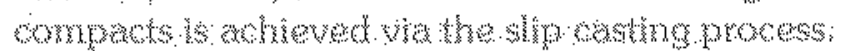

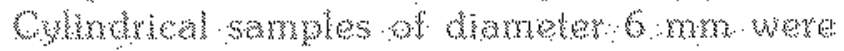

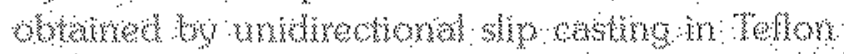

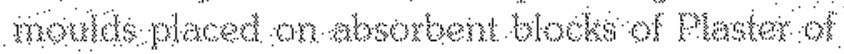

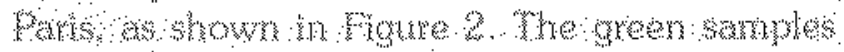
were dred for a mimm of 72 houm sammis

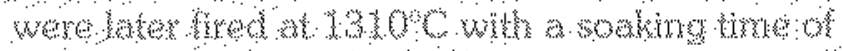




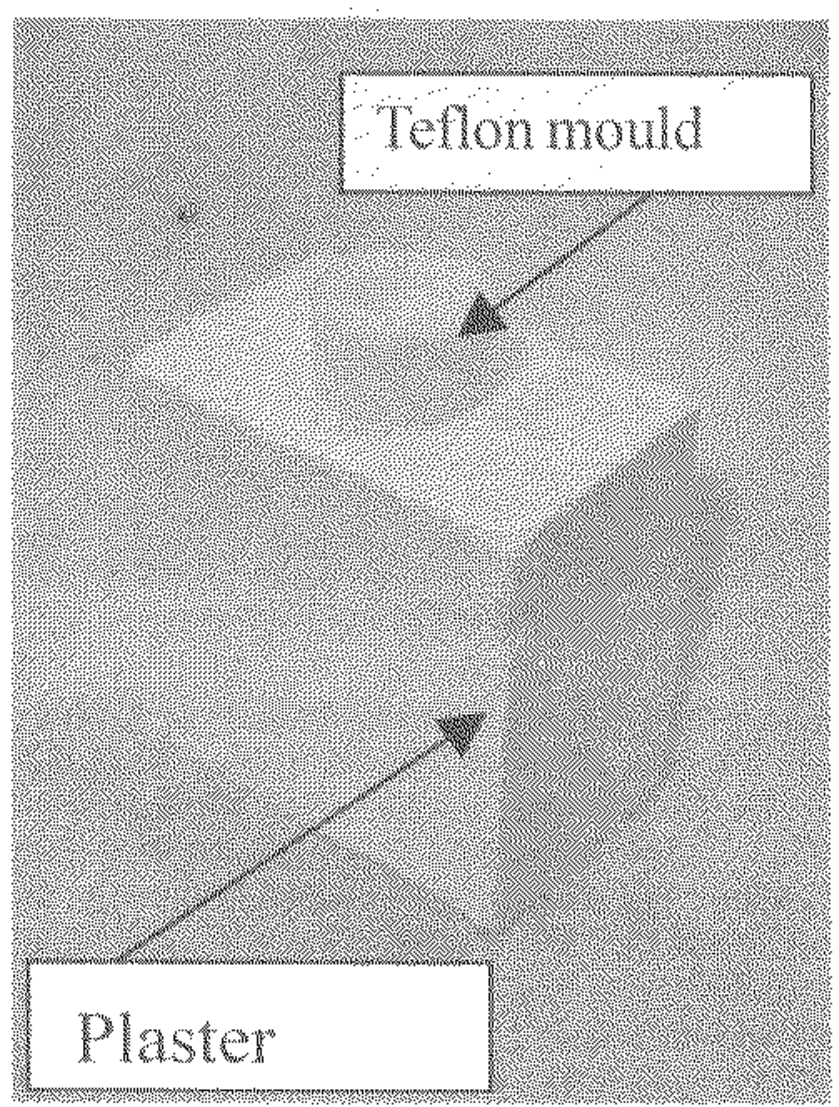

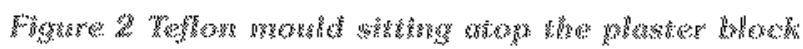
a

one hour LIVW High Tem, VMK 300 . Samples that have been propares at the optum of value were also sintered at varous other sintering

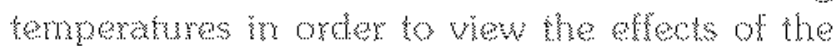
sintering temparare on the microstucure and properties of the semples. Microsturtural analysis was conduchen using a sommo elechon microsope (Phings X.30).

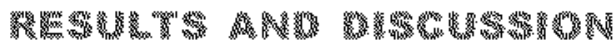

Prevous works have show that the agslomeration of oxide powders in suppensions

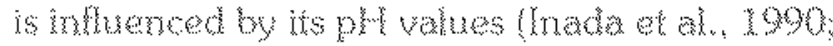

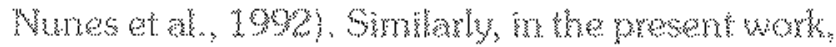
the viscosiny of the suspensions ts found to be a

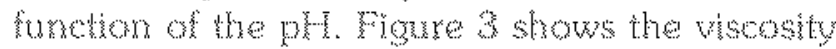

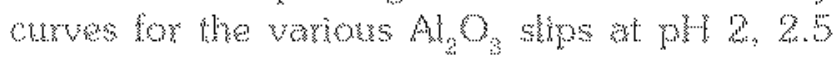
and 3. All thee suspensions displayed shear

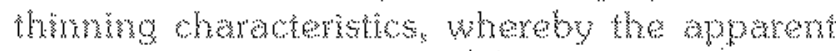

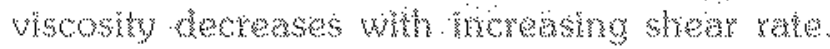
This is generaly the favounde rheological behevour for slips used m slip casting. In theory. a less agolomereted suspension will yiet lower

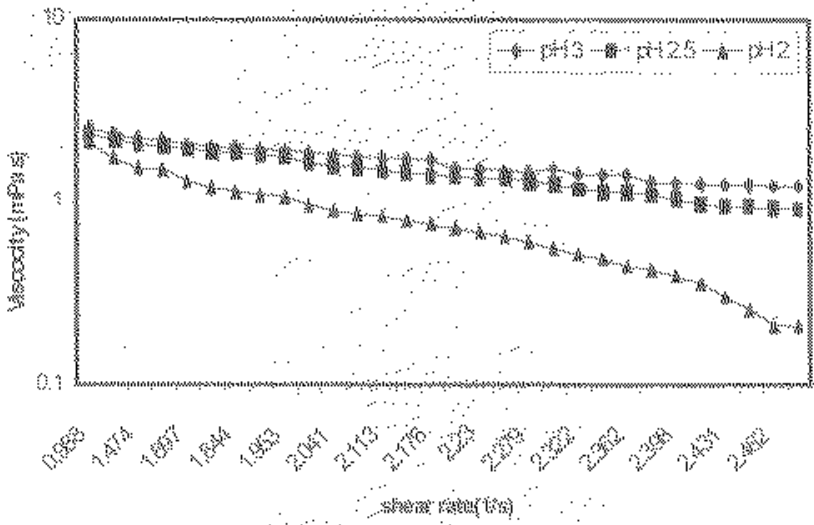

Fon

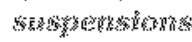

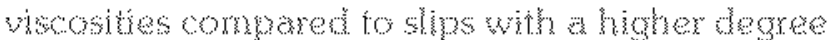
of agoloneraton. Accordingly, it demonstrates wat the pH. 2 suspenwon is least acolomerated compared to the onter two suspensions of pri 2.5 and 3 .

Furber andurical work is then carred out by examping antered samples moter the semming

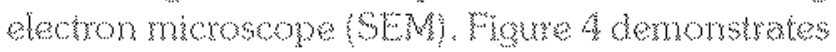
the drerence between the merostuchure of samples prepared at py 2 and pll 3 . It to noted that SEM morograptis of samples prepared at $\mathrm{xH}$ 2.5.ndicated simblar microstructures to those of pH 3 samples, and therefore not show here. In much the same way as previously manesested in migne 3 , me ph 2 amples behaved dferenty fron the others, showing a micostructure that is completely dhern compared to those sumples prepared athe hoher ph volues. Whereas, there is lardy any evidence of an onser of sintemg on

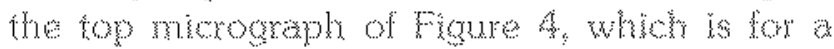
sarrole prepared at ril 3 the microgaply on the right shows that the mothat sintering process has

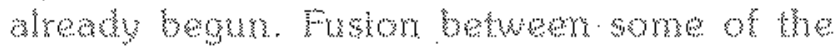

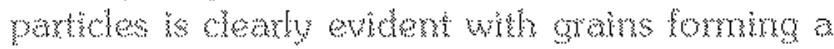
more angular shave. In cortrast the partich on

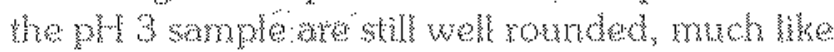

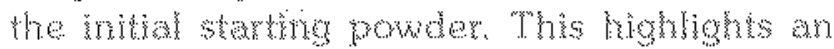

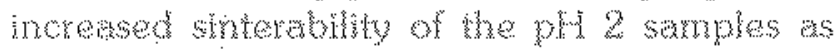
compared to the others. Additonally the ph 3 samplos abwed the asolomeration of the pardecs

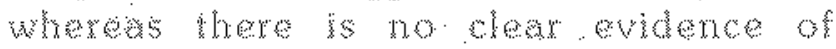

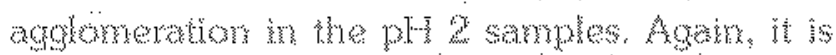

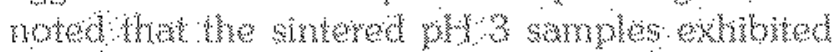

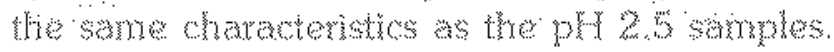

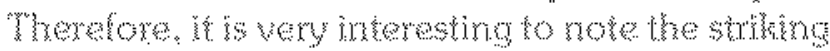
diference beween the ply 2 and wit 2 samples 

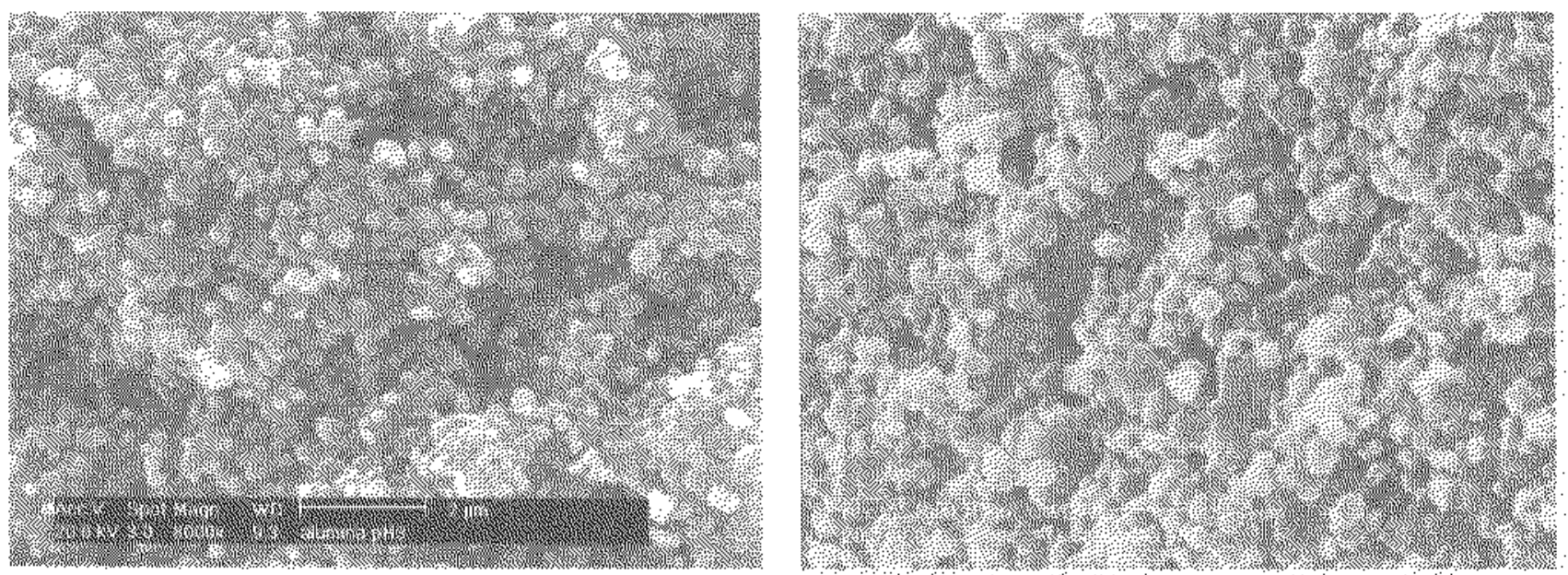

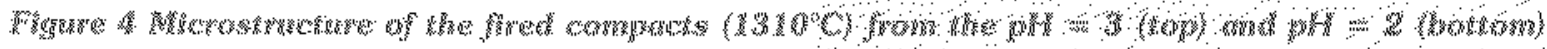

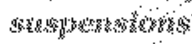

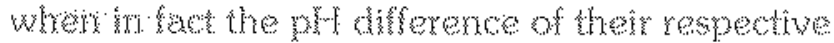

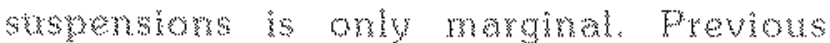

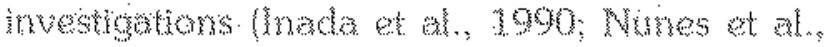

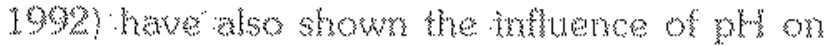

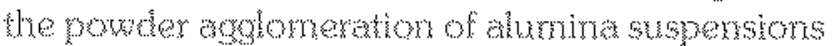
but then works were conducted on a worderange

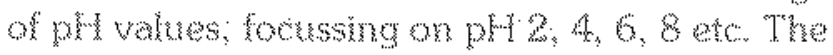
present stury, on whe other hand, has chown that

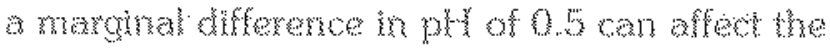

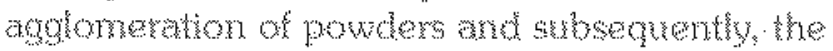
sinterabluty a the compats.

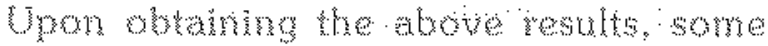

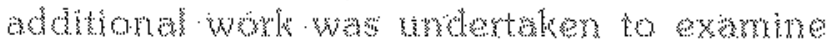

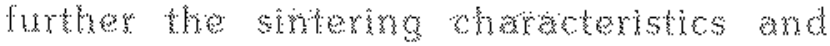

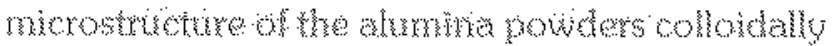

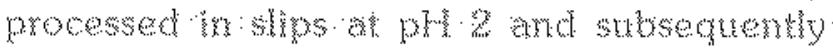

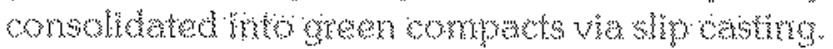
These were then sintered at varumg tempertures of $1370,4350,1425,4500$ and 15500 . Onee

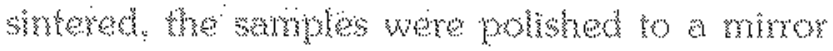

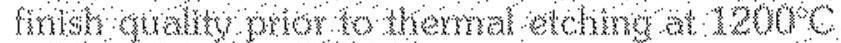

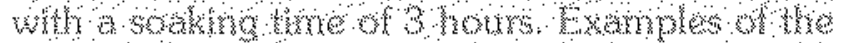

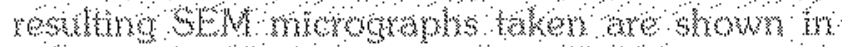

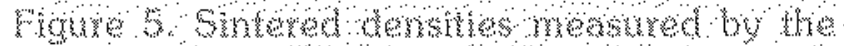

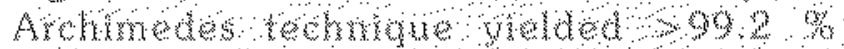

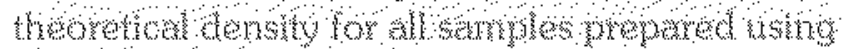

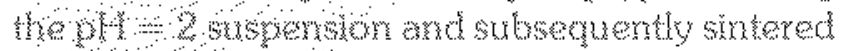

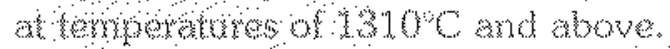

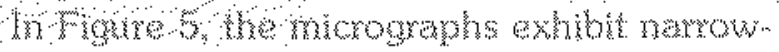

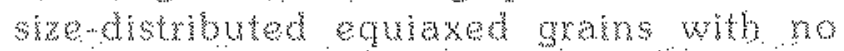
exaggerated gran growh, even ar the highest sintering temparatre of $550 \mathrm{C}$. As expected, the

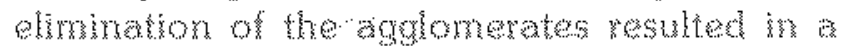

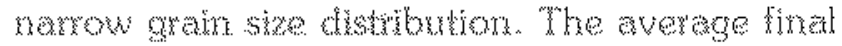
gran size masured whing the limear interept

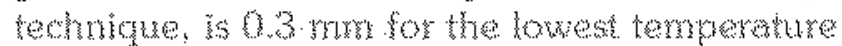
and about $2 \mathrm{~g}$ mm for the highest tenperature uswal, as shomm in migure 6 , whe results of an earlier wokk (Muchar, 1999 ) on anothe alumina

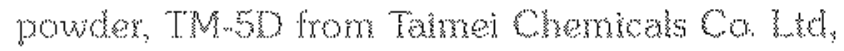

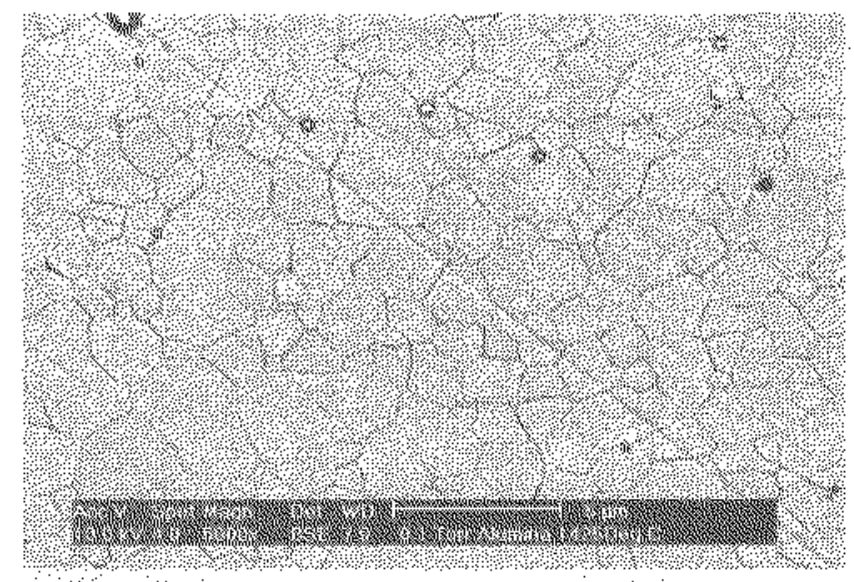

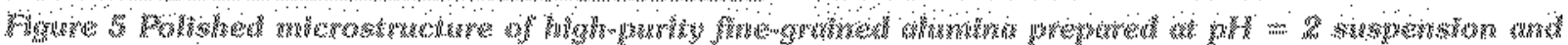

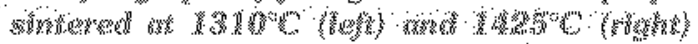




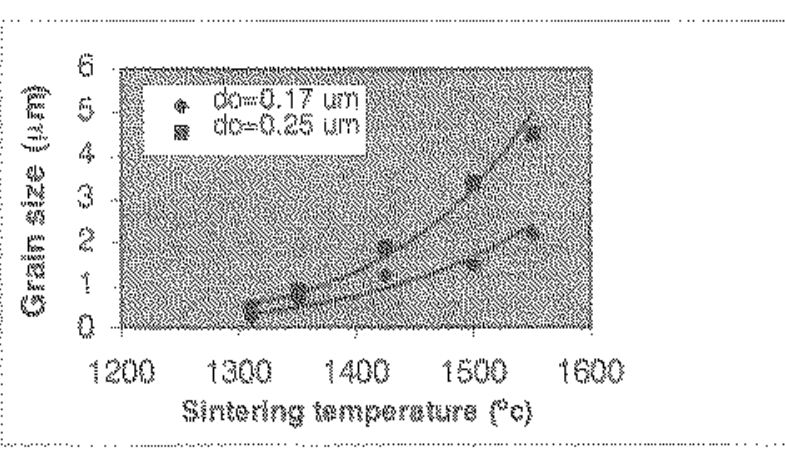

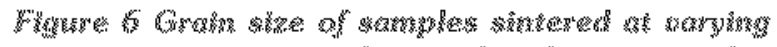

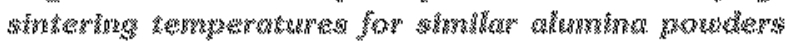

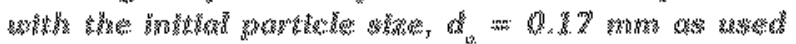

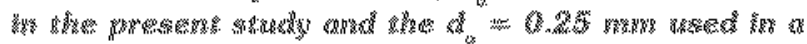

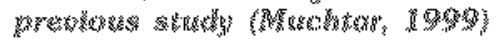

Japan with an average initul particle size of 0.25

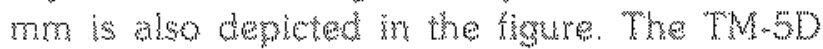
powder susponsion was also prepared at pow 2 and bllowed the same processing route as the powder used in the present sudy. It is cleanty

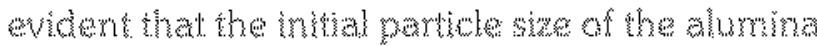
powders deteminas the find gran wow of the sintere samples. A smater mitral paricle size

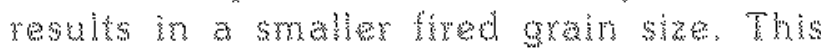

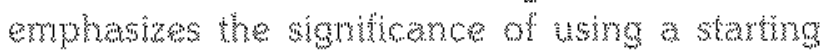

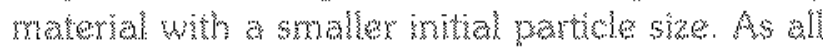
other things being equal, the machanical

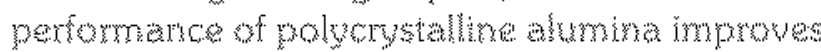
Whto a reduction in grain sise Muchar and Lim,

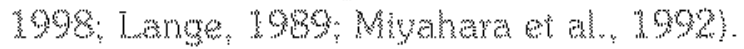

\section{Cor on}

The reat of this sudy has proven thet a careful pH control of the suspension is necessury for the deagctomeration of high-purizy and findsired alurina powder, ensuring a successtut colloinal processmg of the powders. The rheological work has indicated that the pH 2 susperstons have a much low viscosity compared to those of $\mathrm{pH} 2.5$ and 3 . Upon companing the SEM mincroraph of the fred samples, the pH 2 samples showed hatte or no agolomeraton. In contrest. semples which ware rot processed at ph 2 showed much agglomeration of the alumina particles. It is atso show that a a low fining temperature of $1310^{\circ} \mathrm{C}$. the pH 2 sammles have already started the sintermo process whereas the other samples have yet to manifest whe onset of sintering. In conchaion, the present work has shown that fine

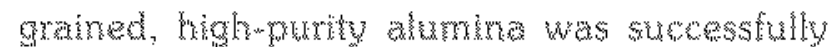
deaglomerated via colloidal processing at. pH 2

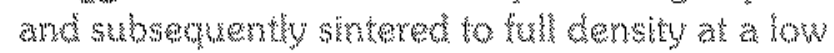
remperature of " $310 \mathrm{C}$ when one hour soakng urrne.

\section{CANOW W}

The athors would like wo achomledge Uriversin Kebangsan Mataysia and the Malaysian Government for supporting this regatch through 1BPA grant 05-102.02-0047. We

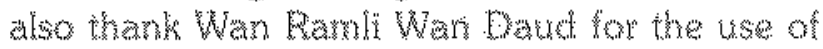

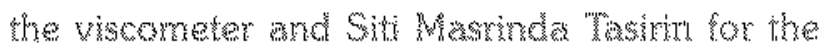
we of the kaser particle size analyser.

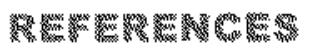

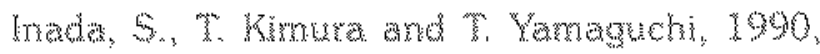
"Wifer of Greer Compat Structura on the sintering of Alumina", Ceromics International, 16, pw. 369-378.

Langer Fon, 1989 "powder processing Sclence

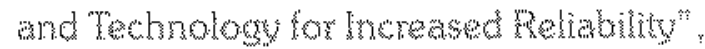
3. Am. Ceram Soc. 72, [1], pw. 3-15.

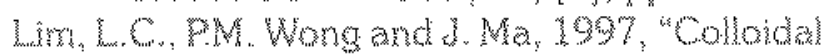
Processing of Sub-Micron Altmma

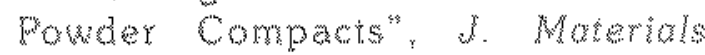

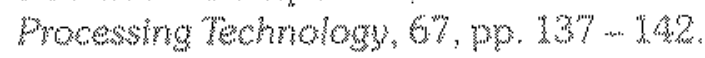

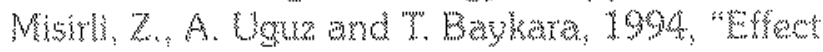
of Additives on the Mardotweture and Mechenical propertes of Commertias Alumina Ceramios", Moterials Characterwation, 3, pp. 329-34.

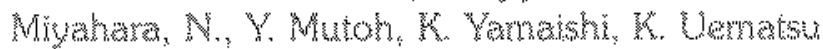

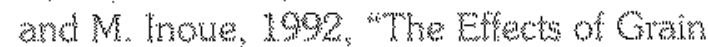
Size on Strength. Fracture Toughness and

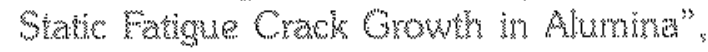
In $I F C C$ Wortwho series: Moterials Processing and Desink: Cram boundary Commollad Propentes of Fine Carwios, $\mathrm{K}$

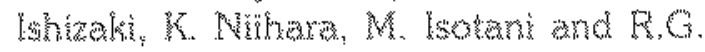
Fork (ews), Elseviex Science Pubishers.

Muchtar, A., 1999, "Simtering Characteristics and Merostrumber of Collotdaly processed

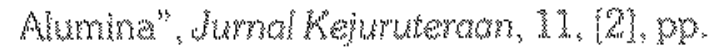
$3-12$.

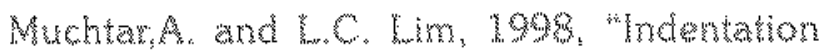
Fracture Toughness of Hoh Purtu

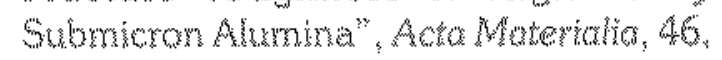
\$6. ph. $1683-3600$ 
Nunes,F., A.G. Lamas, M. Almeida and H.M.M. Diz, 1992, "Influence of Deflocculants on the Characteristics of Alumina Bodies Obtained by Slip Casting", J. Mater. Sci., 27, pp. $6662-6666$.

Suzuki, T.S., Y. Sakka, K. Nakano and K. Hiraga, 1998, "Effect of Ultrasonification on Colloidal Processing of $\mathrm{Al}_{2} \mathrm{O}_{3}$ and $\mathrm{ZrO}_{2}$ Powders in $\mathrm{Ph}$ Controlled Suspension", Materials Transaction, JIM, 39 (6): 689 692.

Tari, G., J.M.F. Ferreira, A.T. Fonseca and O. Lyckfeldt, 1998, "Influence of Particle Size Distribution on Colloidal Processing of Alumina", Journal of the European Ceramic Society, 18, pp. $249-253$.

Yeh, T-S. and M.D. Sacks, 1988, "Lowtemperature Sintering of Aluminium Oxide", J. Am. Ceram. Soc., 71, [10], pp. $841-844$. 